\title{
THE QUALITY IMPROVEMENT OF CONCRETE PAVING PRODUCTS USING TAGUCHI METHODS
}

\author{
Yulia Dwi Angelina and Sunday Noya \\ Industrial Engineering Study Program Universitas Ma Chung \\ e-mail: 411010029@student.machung.ac.id, sunday.alexander@mahung.ac.id
}

\begin{abstract}
The manufacturing industries in Indonesia have been improving rapidly thus make the industries to be in ore competitive environment. This research is conducted to design a refinement or quality improvement for paving products in PT. Malang Indah. The quality improvement is done with Taguchi method experimental design in order to get optimal mixture combination. As for the orthogonal array notation used is $L_{9}\left(3^{4}\right)$ with cement (A), fly ash (B), and sand (C) as the controlling factors. The data processing will be done with ANOVA calculation towards the average value and SNR with larger the better as classification. The ANOVA calculation is done in order to find out the significantly influential factors in product durability. The test done to find out the product durability is a pressure test which is done with compression machine. According to the result of data processing, the ratio of optimal mixture composition cement: fly ash: sand is 1:3:6 $\left(A_{1}, B_{2}\right.$, and $\left.C_{3}\right)$. A confirmation experiment will be done to the optimal composition during the control stage to find out the validity. According to the calculation in confirmation experiment, the result for pressure durability is $450,117 \mathrm{~kg} / \mathrm{cm}^{2}$ which indicate the quality of paving category a based on SNI 03-0691-1996.
\end{abstract}

Keywords: Quality Improvement, Taguchi Method

\begin{abstract}
ABSTRAK
Industri manufaktur di Indonesia telah berkembang pesat sehingga membuat industri berada di lingkungan yang kompetitif. Penelitian ini dilakukan untuk merancang perbaikan atau peningkatan kualitas untuk produk paving di PT. Malang Indah. Peningkatan kualitas dilakukan dengan metode Taguchi untuk mendapatkan kombinasi campuran optimal. Adapun notasi array orthogonal yang digunakan adalah $L_{9}\left(3^{4}\right)$ dengan semen (A), fly ash (B), dan pasir (C) sebagai faktor pengendali. Pengolahan data akan dilakukan dengan perhitungan ANOVA terhadap nilai rata-rata dan SNR dengan klasifikasi larger the better. Perhitungan ANOVA dilakukan untuk mengetahui faktor-faktor yang berpengaruh secara signifikan terhadap daya tahan produk. Tes yang dilakukan untuk mengetahui daya tahan produk adalah tes tekanan yang dilakukan dengan mesin kompresi. Berdasarkan hasil pengolahan data, rasio optimal komposisi campuran semen: abu: pasir adalah 1:3: 6 (A1, B2, dan C3). Eksperimen konfirmasi kemudian dilakukan dengan komposisi optimal selama tahap kontrol untuk mengetahui validitas. Menurut perhitungan dalam percobaan konfirmasi, hasil tekanan daya tahan adalah 450.117 $\mathrm{kg} / \mathrm{cm} 2$ yang menunjukkan kualitas paving kategori A berdasarkan SNI 03-0691-1996.
\end{abstract}

Kata kunci: Quality Improvement, Metode Taguchi

\section{INTRODUCTION}

The development of industries in Indonesia is increasing day by day. This rapid industrial growth result in more competitive environment between companies. Therefore, a company needs to do an effort in order to survive in a competitive industrial environment. One thing that should always be noticed is the quality of products. A company which is able to produce high quality either goods or service will have greater chance to survive, even win the competition and earn maximum profit [1]. The effects of industrial rapid growth are also took effect on PT. Malang Indah as one of the industries that labor in manufacturing. This company produces several building material such as roofs, paving blocks, and roadblocks. There are two kinds of paving blocks that are produced by PT. Malang Indah, square blocks and hexagonal blocks. The company focuses in product quality which is done by refining or developing the quality gradually in various aspects. We know that a product have a good quality if the product have fulfilled or even exceeded customers' expectation. Product quality can be refined or improved by applying DMAIC approach (Define, Measure, Analyze, Improve, and Control). The DMAIC approach 
focuses on continuous quality improvement and is done systematically based on available facts and knowledge [2]. The improve phase will be done with Taguchi method.

\section{RESEARCH METHOD}

The method used in this research begins with initial observation until conclusion and suggestion. The method of this study could be seen in following flow chart:

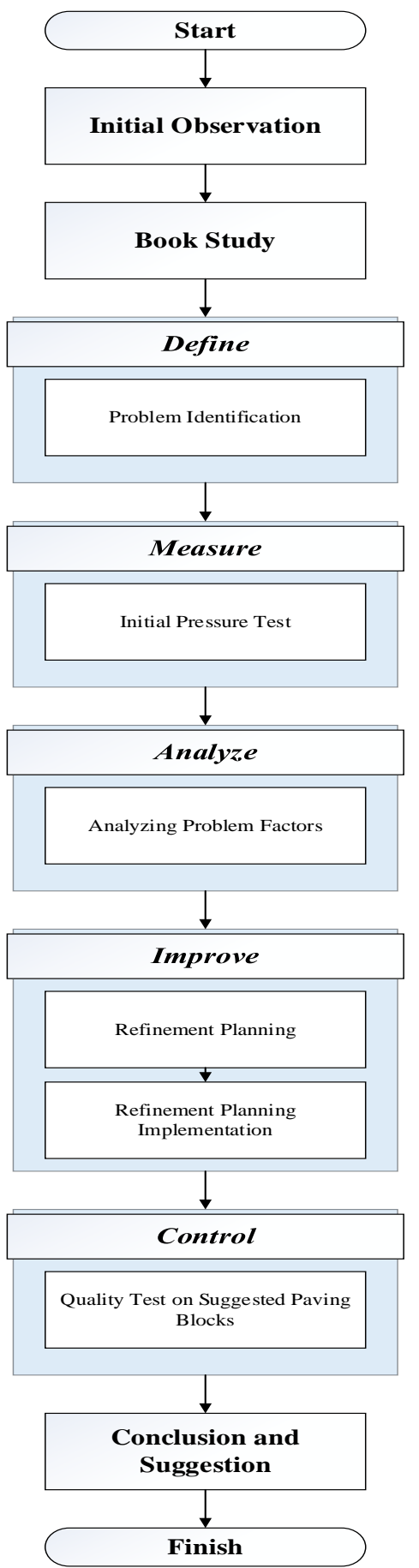

Figure 1. Research Flow Chart

\section{Define Stage}

\section{RESULT AND DISCUSSION}

In this first stage, the problems from the initial observation will be identified. The identified problem is the poor quality of PT. Malang Indah paving blocks. This could be proven with the result of the initial test (drop test). Based on the test result, some paving blocks were damaged which indicates that the quality of the blocks are still poor. During this Define stage SIPOC chart will be used as process mapping. This SIPOC chart is made to discover the flow of paving production process at PT. Malang Indah, identify all elements, and help observing the relation between the process along with input and output. The following chart is the SIPOC chart of PT. Malang Indah (Figure 2).

\section{Measure Stage}

During the Define stage, a problem with PT. Malang Indah product quality has been. Based on the result from Drop test, several products were damaged when dropped from about 1 meter height. Therefore, there will be a measuring process on PT. Malang Indah paving blocks to define the exact quality. The quality measurement is done using compression machine which will show the pressure durability of the paving blocks. The following is the test result of five paving blocks (Table 1).

Based in the test result, the average durability of each paving blocks is 83,305 $\mathrm{kg} / \mathrm{cm}^{2}$. The values shown are still below the quality standard. This could be seen on paving blocks standard quality according to SNI 03-0691-1996. According to SNI 03-06911996, the quality of D class paving blocks (the lowest) have the average durability of 86,646 $101,937 \mathrm{~kg} / \mathrm{cm}^{2}$. The quality of paving blocks is still below the standard and it needs to be refined or improvement in quality.

\section{Analyze Stage}

According to the quality measurement on the current paving blocks, it is known that the quality of the paving blocks produced by PT. Malang Indah is still below the standard. Therefore, it is needed to conduct further research to find out the cause of the poor 
product quality. The following is the analysis Malang Indah using cause-and-effect diagram result of the poor quality products at PT. (Figure 3).

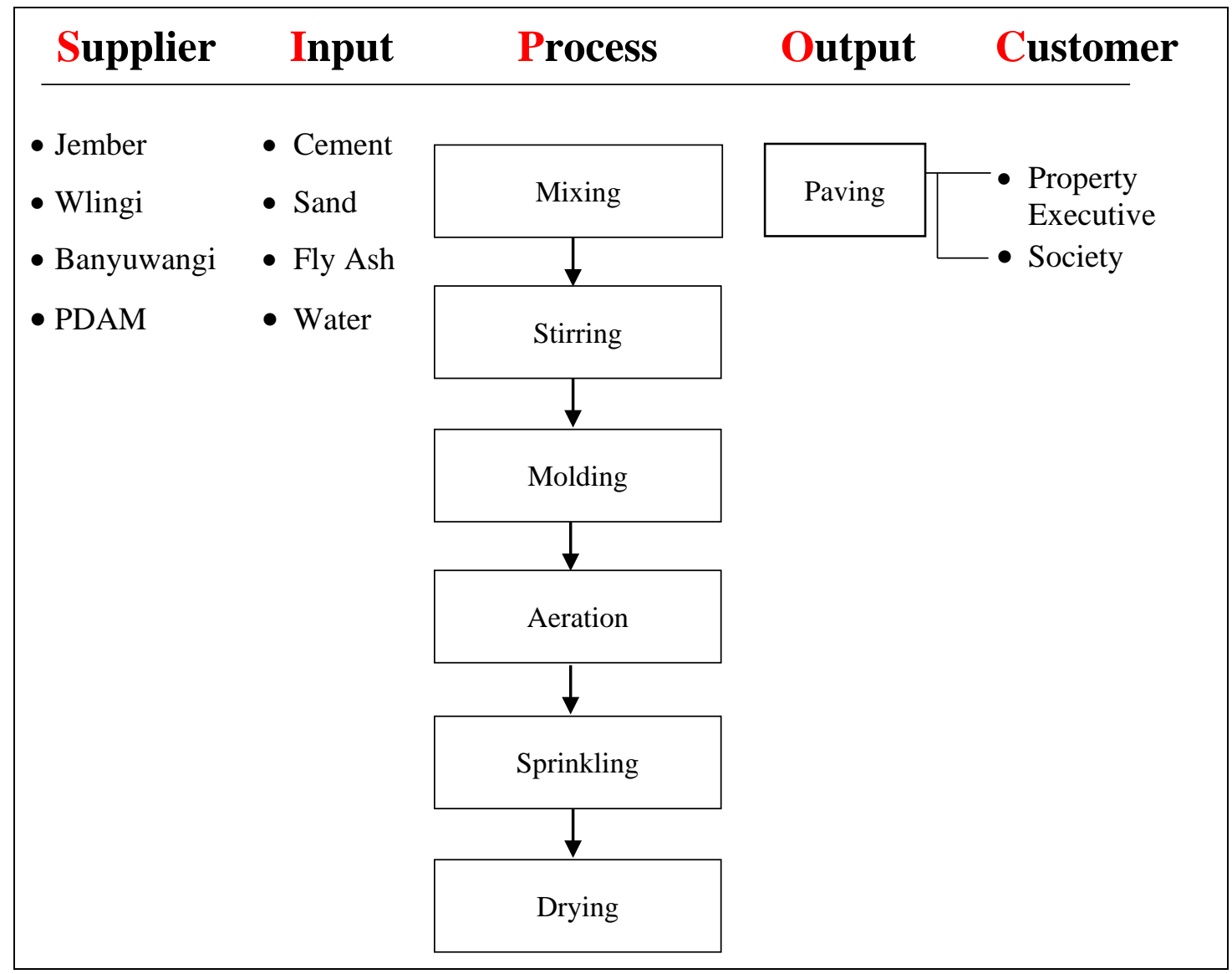

Figure 2. SIPOC Chart in PT. Malang Indah

Table 1. Paving Blocks Initial Test

\begin{tabular}{ccrrrr}
\hline \multirow{2}{*}{ No. } & $\begin{array}{c}\text { Paving } \\
\text { Lifetime }\end{array}$ & $\begin{array}{c}\text { Pressure } \\
\text { Weight }(\mathrm{kN})\end{array}$ & $\begin{array}{c}\text { Weight } \\
\text { Conversion }(\mathrm{kg})\end{array}$ & $\begin{array}{c}\text { Area Width } \\
\left(\mathrm{cm}^{2}\right)\end{array}$ & $\begin{array}{c}\text { Pressure Durability } \\
\left(\mathrm{kg} / \mathrm{cm}^{2}\right)\end{array}$ \\
\hline 1 & 28 day & 108 & $11.012,976$ & 227,947 & 48,314 \\
2 & 28 day & 164 & $16.723,408$ & 215,441 & 77,624 \\
3 & 28 day & 192 & $19.578,624$ & 231,094 & 84,722 \\
4 & 28 day & 201 & $20.496,372$ & 212,703 & 96,362 \\
5 & 28 day & 236 & $24.065,392$ & 219,765 & 109,505 \\
\hline \multicolumn{5}{c}{ Average } \\
\hline
\end{tabular}

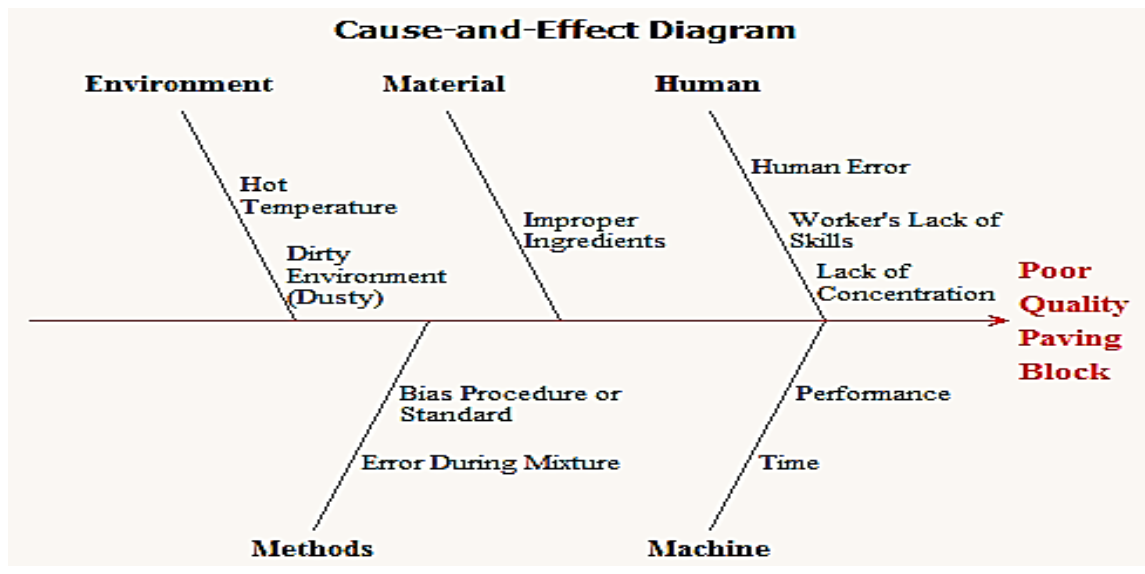

Figure 3. Cause-and-Effect Diagram of Poor Quality Paving 


\section{Improve Stage}

In this stage, there will be a refinement planning for paving blocks quality. From the measurement result, it is known that the paving quality is still below the standard, meanwhile from the analysis using the cause-and-effect chart; it is known that the quality improvement will be focused on material mixture. Focus on material mixture is done because it is impossible to rework the paving blocks that has been molded. This Improve stage will be done with Taguchi experimental design concept which is started from planning, implementation, until processing the experimental data.

Based on cause-and-effect chart in Figure 3 , the controlling factors used for the experiment are materials factor which indicate that the experiment will be focused on material combining. This is because it is impossible to rework the paving blocks that have been molded. The controlling factors used in this experiment are cement, fly ash, and sand. Each factor will be given a level or parameter so that the experiment can be conducted successfully. The level given indicates the comparison between each factor's weight in numbers. Each experiment will be using $20 \mathrm{~kg}$ materials in total. The following is the combination level and the factors which will be used during the experiment (Table 2).

Table 2. Factor and Level Combination

\begin{tabular}{lcccc}
\hline \multirow{2}{*}{ Factor } & \multirow{2}{*}{ Code } & \multicolumn{3}{c}{ Level } \\
\cline { 3 - 5 } & & $\mathbf{1}$ & $\mathbf{2}$ & $\mathbf{3}$ \\
\hline Cement & $\mathrm{A}$ & 1 & 1,5 & 2 \\
Fly Ash & $\mathrm{B}$ & 2 & 2,5 & 3 \\
Sand & $\mathrm{C}$ & 4 & 6 & 8 \\
\hline
\end{tabular}

According to the table above, an orthogonal array matrix with $\mathrm{L}_{9}\left(3^{4}\right)$ notation could be used in this research such as below (Table 3).

\begin{tabular}{cccc}
\multicolumn{3}{c}{ Table 3. Orthogonal Array $\mathrm{L}_{9}\left(3^{4}\right)$} & Matrix \\
\hline \multirow{2}{*}{ Experiment } & \multicolumn{3}{c}{ Factor } \\
\cline { 2 - 4 } & Cement & Fly Ash & Sand \\
\hline 1 & 1 & 1 & 1 \\
2 & 1 & 2 & 2 \\
3 & 1 & 3 & 3 \\
4 & 2 & 1 & 2 \\
5 & 2 & 2 & 3 \\
6 & 2 & 3 & 1 \\
7 & 3 & 1 & 3 \\
8 & 3 & 2 & 1 \\
9 & 3 & 3 & 2 \\
\hline
\end{tabular}

After the experiment is done and the paving blocks have been made for 28 days, then an experiment to measure the pressure durability will be conducted. This pressure test will be conducted with 3 samples for each experiment, so that the total paving that will be used is twenty seven paving blocks. The test result data will be processed to get the average value, SNR with "larger the better" as the classification, ANOVA to find out the influential factors and confidence interval. The following is the data processing for this research.

After getting the value of mean and SNR, the data processing is continued with ANOVA calculation. ANOVA calculation is conducted for "mean" value and also for SNR value. The steps of ANOVA calculation for "mean" and SNR value are similar, as in:

The average value of whole experiment

$$
\bar{y}=\frac{\sum y}{n}
$$

Table 4. Mean and SNR Calculation Result Value

\begin{tabular}{crrrrrr}
\hline \multirow{2}{*}{ Experiment } & \multicolumn{2}{c}{ Pressure Test Result $\left(\mathrm{kg} / \mathrm{cm}^{2}\right)$} & \multirow{2}{*}{ Sum } & \multirow{2}{*}{ Mean $(\mu)$} & \multirow{2}{*}{ SNR } \\
\cline { 2 - 4 } & \multicolumn{1}{c}{1} & \multicolumn{1}{c}{3} & & & \\
\hline 1 & 169,639 & 173,427 & 191,143 & 534,210 & 178,070 & 44,977 \\
2 & 398,662 & 367,118 & 408,995 & $1.174,775$ & 391,592 & 51,829 \\
3 & 320,596 & 335,694 & 331,166 & 987,456 & 329,152 & 50,343 \\
4 & 176,266 & 205,401 & 209,540 & 591,207 & 197,069 & 45,814 \\
5 & 136,305 & 151,016 & 133,376 & 420,697 & 140,232 & 42,899 \\
6 & 208,372 & 221,425 & 217,055 & 646,852 & 215,617 & 46,665 \\
7 & 138,837 & 162,847 & 152,199 & 453,883 & 151,294 & 43,541 \\
8 & 163,155 & 170,439 & 166,942 & 500,536 & 166,845 & 44,442 \\
9 & 232,335 & 223,421 & 237,935 & 693,691 & 231,230 & 47,272 \\
\hline
\end{tabular}


$\bar{y}=\frac{169,639+173,427+191,143+\cdots+237,935}{27}$

$\bar{y}=\frac{6.003,304}{27}=223,345$

The average value for each factor

$\overline{\overline{y_{J k}}}=\frac{\sum \overline{y_{l \jmath k}}}{n_{i j k}}$

$\overline{\overline{y_{A 1}}}=\frac{178,170+391,592+329,152}{3}$

$\overline{\overline{y_{A 1}}}=\frac{898,813}{3}=299,604$

The same calculation will be done for $\mathrm{B}$ and $\mathrm{C}$ factor. After the calculation is done, the result will be put into table and response graphic as shown below:

Table 5. Average Value Response

\begin{tabular}{crrr}
\hline & \multicolumn{3}{c}{ Factor } \\
\cline { 2 - 4 } & Cement (A) & Fly Ash (B) & \multicolumn{1}{c}{ Sand (C) } \\
\hline 1 & 299,604 & 175,478 & 186,844 \\
2 & 184,306 & 232,890 & 273,297 \\
3 & 183,123 & 258,666 & 206,893 \\
\hline Ranking & 1 & 3 & 2 \\
\hline
\end{tabular}

Total sum of square

$S S_{\text {total }}=\sum y^{2}$

$S S_{\text {total }}=169,639^{2}+173,427^{2}+191,143^{2}$ $+\cdots+237,935^{2}$

$S S_{\text {total }}=1.510 .424,907$

Total sum of square due to mean

$$
\begin{aligned}
& S_{m}=n \cdot \bar{y}^{2} \\
& S_{m}=27 \times 22,345^{2} \\
& S_{m}=1.334 .802,404
\end{aligned}
$$

Total sum of square due to factors

$S S_{A}=n_{A 1} \cdot \overline{A 1}^{2}+n_{A 2} \cdot \overline{A 2}^{2}+n_{A 3} \cdot \overline{A 3}^{2}-S_{m}(5)$

$$
\begin{aligned}
S S_{A}=(9 \times 299, & \left.604^{2}\right) \\
& +\left(9 \times 184,306^{2}\right)+\left(9 \times 183,123^{2}\right) \\
& +1.334 .802,404
\end{aligned}
$$

$S S_{A}=80.588,940$

The same calculation will also be applied for $\mathrm{B}$ and $\mathrm{C}$.

Total Square errors

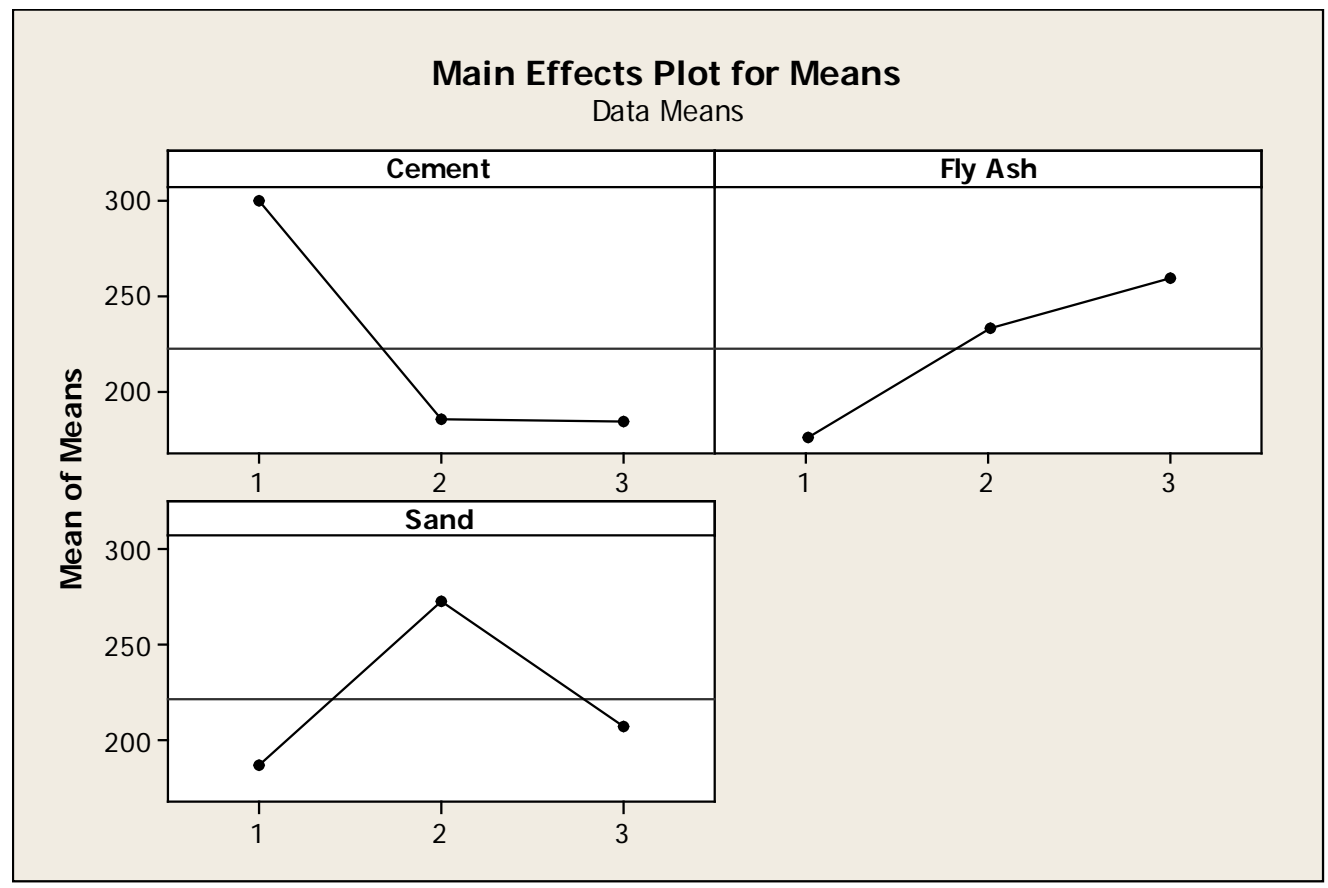

Figure 4. Average Value Response. 


$$
\begin{gathered}
S S_{e}=S S_{\text {total }}-S_{m}-\left(S S_{A}+S S_{B}+S S_{C}\right) \\
S S_{e}=1.510 .424,907-1.334 .802,404 \\
-(80.588,940+32.642,868 \\
+36.856,475)
\end{gathered}
$$

$S S_{e}=25.534,221$

\section{Total average square}

Total average square will be applied on all factors. The following is the example of total average square for factor $\mathrm{A}$ :

$M S_{A}=\frac{80.588,940}{2}=40.294,470$

Total $\mathrm{F}_{\text {ratio }}$

$F_{\text {ratio }}=\frac{M S_{A}}{M S_{E}}$

$F_{\text {ratio }}=\frac{40.294,470}{1276,711}=31,561$

Total pure sum of square value

$S S_{A}^{\prime}=S S_{A}-D F_{A} \cdot M S_{e}$

$S S_{A}^{\prime}=80.588,940-(2 \times 1276,711)$

$$
S S_{A}^{\prime}=78.035,518
$$

Total contribution percentage

$\rho_{A}=\frac{S S_{A}^{\prime}}{S S_{t}} \times 100 \%$

$\rho_{A}=\frac{78.035,518}{176.622,503} \times 100 \%=44,434 \%$

Total ANOVA result will be summarized in the table below (Table 6).

According to the table above, then a test on hypothesis could be conducted by comparing

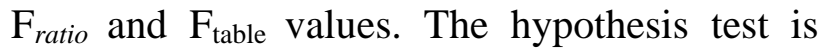
conducted to find out which factor has significant influence towards paving blocks' pressure durability. The result of hypothesis test according to ANOVA calculation above is:

Cement

$\mathrm{H}_{0}$ : Cement has no effect on concrete paving pressure durability.

$\mathrm{H}_{1} \quad$ : Cement has effect on concrete paving pressure durability.

$F_{\text {ratio }}: 31,561$

Conclusion: $\mathrm{F}_{\text {ratio }}>\mathrm{F}_{\text {tabel }}, \mathrm{H}_{0}$ rejected, it means that cement has influence in concrete paving pressure durability.

Fly Ash

$\mathrm{H}_{0} \quad$ : Fly ash has no effect on concrete paving pressure durability.

$\mathrm{H}_{1} \quad$ : Fly ash has effect on concrete paving pressure durability.

$F_{\text {ratio }}: 12,784$

Conclusion: $\mathrm{F}_{\text {ratio }}>\mathrm{F}_{\text {tabel }}, \mathrm{H}_{0}$ rejected, it means that fly ash has influence in concrete paving pressure durability.

Sand

$\mathrm{H}_{0} \quad$ : Sand has no effect on concrete paving pressure durability.

$\mathrm{H}_{1} \quad$ : Sand has effect on concrete paving pressure durability

$F_{\text {ratio }}: 14,434$

Conclusion: $F_{\text {ratio }}>F_{\text {tabel }}, \mathrm{H}_{0}$ rejected, it means that sand has influence in concrete paving pressure durability.

In Taguchi method, it is recommended to calculate ANOVA value after pooling up. Pooling up is the integration between factors with lowest significance as error. The purposes of pooling up are to prevent over estimation and

Table 6. Total ANOVA Result per Ratio

\begin{tabular}{crrrrrrr}
\hline Source & \multicolumn{1}{c}{ SS } & DF & MS & F ratio & SS & \multicolumn{1}{c}{$\begin{array}{c}\text { Ratio } \\
(\%)\end{array}$} & $F_{\text {table }}$ \\
\hline $\mathrm{A}$ & $80,588.940$ & 2 & $40,294.470$ & 31.561 & $78,035.518$ & 44.434 & 3.403 \\
$\mathrm{~B}$ & $32,642.868$ & 2 & $16,321.434$ & 12.784 & $30,089.445$ & 17.133 & 3.403 \\
$\mathrm{C}$ & $36,856.475$ & 2 & $18,428.237$ & 14.434 & $34,303.053$ & 19.532 & 3.403 \\
\hline Error & $25,534.221$ & 20 & $1,276.711$ & 1 & $33,194.488$ & 18.901 & \\
SS & 175.622 .503 & 26 & & & $175,622.503$ & 100 & \\
Mean & $1,334,802.404$ & 1 & & & & & \\
\hline SS $_{\text {total }}$ & $1,510,424.907$ & 27 & & & & & \\
\hline
\end{tabular}


to minimize the errors during the experiment. Table 7 is the result of ANOVA calculation after pooling up.

According to the ANOVA calculation table after pooling up, the percentage of contribution is $39,149 \%$. This indicates that the factor which has significance influence or contribution towards average value is enough to be involved in the experiment (the condition is contribution percentage $\leq 50 \%$ ). ANOVA calculation result towards SNR value could be seen in appendix 2. After getting ANOVA result towards average value and SNR, then the optimal setting level could be applied as shown below (Table 8):

After getting the optimal setting level, then the reliance value will be calculated to be compared with the result of confirmation experiment value. This reliability interval calculation is used for calculating the average value and also SNR.

The next is calculating the reliability interval for optimal condition and confirmation either for average value and SNR. The optimal condition reliability interval for the average is started with calculating $\mu_{\text {prediction }}$ first. The calculation to get the reliability interval could be seen as below: estimation

Calculating $\mu_{\text {prediction }}$ or optimal condition

$$
\mu_{\text {prediction }}=\bar{y}+\left(\overline{A_{1}}-\bar{y}\right)+\left(\overline{B_{3}}-\bar{y}\right)+\left(\overline{C_{2}}-\bar{y}\right)
$$

$$
\begin{aligned}
\mu_{\text {prediction }}= & \overline{A_{1}}+\overline{B_{3}}+\overline{C_{2}}-2 x \bar{y} \\
\mu_{\text {prediction }}= & 299,604+258,666+273,297 \\
& -2 x 223,345 \\
\mu_{\text {prediction }}= & 387,507 \mathrm{~kg} / \mathrm{cm}^{2}
\end{aligned}
$$

\section{Calculating $\mathbf{C I}_{\text {mean }}$}

Before calculating $\mathrm{CI}_{\text {mean }}$, the calculation on $\mathrm{n}_{\mathrm{eff}}$ needs to be done first. $\mathrm{n}_{\mathrm{eff}}$ could be seen as below:

$n_{\text {eff }}=\frac{\text { Total number of experiments }}{\text { Total DF in average estimation }}$

$$
\begin{aligned}
& n_{e f f}=\frac{9 \times 3}{D F_{\mu}+D F_{A}+D F_{B}+D F_{C}} \\
& n_{e f f}=\frac{27}{1+2+2+2}=3,857
\end{aligned}
$$

\begin{tabular}{|c|c|c|c|c|c|c|c|}
\hline Source & SS & DF & MS & $\mathrm{F}_{\text {ratio }}$ & SS' & $\begin{array}{c}\text { Ratio } \\
(\%)\end{array}$ & $\mathrm{F}_{\text {table }}$ \\
\hline A & $80,588.940$ & 2 & $40,294.470$ & 15.238 & $75,300.113$ & 42.876 & 5.614 \\
\hline B & $32,642.868$ & - & - & - & - & - & - \\
\hline $\mathrm{C}$ & $36,856.475$ & 2 & $18,428.237$ & 6.969 & $31,567.649$ & 17.975 & 5.614 \\
\hline Error & $25,534.221$ & - & - & - & - & - & - \\
\hline Pooled & $58,177.089$ & 22 & $2,644.413$ & 1 & $68,754.741$ & 39.149 & \\
\hline $\mathrm{SS}_{\mathrm{t}}$ & $175,622.503$ & 26 & & & $175,622.503$ & 100 & \\
\hline Mean & $1,334,802.404$ & 1 & & & & & \\
\hline $\mathrm{SS}_{\text {total }}$ & $1,510,424.907$ & 27 & & & & & \\
\hline
\end{tabular}

After getting $\mathrm{n}_{\text {eff }}$ value, then $\mathrm{CI}_{\text {mean }}$ could be conducted as below:

$$
\begin{aligned}
& C I_{\text {mean }}= \pm \sqrt{F_{(\alpha ; v 1 ; v 2)} x M S_{e} x\left|\frac{1}{n_{\text {eff }}}\right|} \\
& C I_{\text {mean }}= \pm \sqrt{F_{(0,05 ; 1 ; 22)} x 2644,413 x\left|\frac{1}{3,857}\right|} \\
& C I_{\text {mean }}= \pm \sqrt{4,301 \times 2644,413 \times 0,259} \\
& C I_{\text {mean }}= \pm \sqrt{2945,768}
\end{aligned}
$$

Table 7. Total ANOVA result after Pooling Up

Table 8. Optimal Setting Level

\begin{tabular}{ccccc}
\hline Factor & Code & Level & Ratio & Conversion (kg) \\
\hline Cement & A & 1 & 1 & 2 \\
Fly Ash & B & 3 & 3 & 6 \\
Sand & C & 2 & 6 & 12 \\
\hline
\end{tabular}


$C I_{\text {mean }}= \pm 54,275$

According to the calculation above, then the reliability interval could be calculated as below:

$\mu_{\text {prediction }}-C I_{\text {mean }} \leq \mu_{\text {prediction }} \leq \mu_{\text {prediction }}+$ $C I_{\text {mean }}$

$387,507-54,275 \leq \mu_{\text {prediction }}$ $\leq 387,507+54,275$

$333,232 \leq \mu_{\text {prediction }} \leq 441,782$

The same calculation could be applied for $\mathrm{SNR}$ value. The calculation for $S N R_{\text {prediction }}$ and $\mathrm{CI}_{S N R}$ for SNR value:

The optimal condition value for SNR:

$S N R_{\text {prediction }}=\overline{S N R}+\left(\overline{A_{1}}-\overline{S N R}\right)+$ $\left(\overline{B_{3}}-\overline{S N R}\right)+\left(\overline{C_{2}}-\overline{S N R}\right)$

$S N R_{\text {prediction }}=\overline{A_{1}}+\overline{B_{3}}+\overline{C_{2}}-2 x \overline{S N R}$

$$
\begin{aligned}
S N R_{\text {prediction }} & =49,050+48,093+48,305 \\
& -2 x 46,420
\end{aligned}
$$

$S N R_{\text {prediction }}=52,608 \mathrm{~kg} / \mathrm{cm}^{2}$

$\mathrm{CI}_{S N R}$ Calculation

$C I_{\mathrm{SNR}}= \pm \sqrt{F_{(\alpha ; v 1 ; v 2)} x M S_{e} x\left|\frac{1}{n_{e f f}}\right|}$

$C I_{\mathrm{SNR}}= \pm \sqrt{F_{(0,05 ; 1 ; 4)} x 1,833 x\left|\frac{1}{1,286}\right|}$

$C I_{\mathrm{SNR}}= \pm \sqrt{7,709 \times 1,833 \times 0,778}$

$C I_{\mathrm{SNR}}= \pm \sqrt{10,994}$
$C I_{\mathrm{SNR}}= \pm 3,316$

Based on the calculation above, then the reliability interval could be applied for SNR value as shown below (Table 10):

$S N R_{\text {prediction }}-C I_{S N R} \leq S N R_{\text {prediction }} \leq$

$S N R_{\text {prediction }}+C I_{S N R}$

$52,608-3,316 \leq S N R_{\text {prediction }}$

$\leq 52,608+3,316$

$49,292 \leq S N R_{\text {prediction }} \leq 55,924$

\section{Control Stage}

In this stage a confirmation experiment will be done to find out if the suggested mixture could be accepted. The following table is the result of confirmation experiment using the suggested mixture:

According to the data in the table above, then a calculation on reliability interval can be applied to be compared with the reliability interval in optimal condition. The following is the result of reliability interval calculation from confirmation experiment for average value and SNR:

$\mu=\frac{1}{n} \sum_{i=1}^{n} y_{i}$

$\mu=\frac{1}{5}(464,882+464,014+\cdots+440,699)$

$\mu=450,117$

SNR calculation value

$S N R=-10 \log \left[\frac{1}{n} \sum_{i=1}^{n} \frac{1}{y_{i}^{2}}\right]$

Table 10. Confirmation Experiment Result Table

\begin{tabular}{cccrrrr}
\hline No. & $\begin{array}{c}\text { Experiment } \\
\text { Date }\end{array}$ & $\begin{array}{c}\text { Paving } \\
\text { Lifetime }\end{array}$ & $\begin{array}{c}\text { Pressure } \\
\text { Mass }(\mathrm{kN})\end{array}$ & $\begin{array}{c}\text { Mass Conversion } \\
(\mathrm{kg})\end{array}$ & $\begin{array}{c}\text { Area Width } \\
\left(\mathrm{cm}^{2}\right)\end{array}$ & $\begin{array}{c}\text { Pressure Power } \\
\left(\mathrm{kg} / \mathrm{cm}^{2}\right)\end{array}$ \\
\hline 1 & 21 Mei 2014 & 28 day & 978 & $99.728,616$ & 214,524 & 464,882 \\
2 & 21 Mei 2014 & 28 day & 1001 & $102.073,972$ & 215,723 & 464,014 \\
3 & 21 Mei 2014 & 28 day & 903 & $92.080,716$ & 211,156 & 436,080 \\
4 & 21 Mei 2014 & 28 day & 921 & $93.916,212$ & 211,091 & 444,909 \\
5 & 21 Mei 2014 & 28 day & 914 & $93,202,408$ & 211,488 & 440,699 \\
\hline
\end{tabular}




$$
\begin{gathered}
\operatorname{SNR}=-10 \log \left[\frac { 1 } { 5 } \left(\frac{1}{464,882^{2}}+\frac{1}{464,014^{2}}+\cdots\right.\right. \\
\left.\left.+\frac{1}{440,699^{2}}\right)\right]
\end{gathered}
$$

$S N R=53,057$

Reliability interval for average value

$$
\begin{aligned}
& C I_{\text {mean }}= \pm \sqrt{F_{(\alpha ; v 1 ; v 2)} x M S_{e} x\left|\frac{1}{n_{e f f}}+\frac{1}{r}\right|} \\
& C I_{\text {mean }}= \pm \sqrt{F_{(0,05 ; 1 ; 22)} x 2644,413 x\left|\frac{1}{3,857}+\frac{1}{5}\right|} \\
& C I_{\text {mean }}= \pm \sqrt{4,301 \times 2644,413 \times 0,459} \\
& C I_{\text {mean }}= \pm 72,253
\end{aligned}
$$

Reliability interval for average value:

$$
\begin{aligned}
& \mu_{\text {Confirmation }}-C I_{\text {mean }} \leq \mu_{\text {Confirmation }} \leq \\
& \mu_{\text {Confirmation }}+C I_{\text {mean }}
\end{aligned}
$$

$$
\begin{array}{r}
450,117-72,253 \leq \mu_{\text {Confirmation }} \\
\leq 450,117+72,253 \\
377,864 \leq \mu_{\text {Confirmation }} \leq 522,370
\end{array}
$$

Reliability interval for SNR value:

$$
C I_{S N R}= \pm \sqrt{F_{(\alpha ; v 1 ; v 2)} x M S_{e} x\left|\frac{1}{n_{e f f}}+\frac{1}{r}\right|}
$$

$$
C I_{S N R}= \pm \sqrt{F_{(0,05 ; 1 ; 4)} x 1,833 x\left|\frac{1}{1,286}+\frac{1}{5}\right|}
$$

$C I_{S N R}= \pm \sqrt{7,709 \times 1,833 \times 0,978}$

$$
C I_{S N R}= \pm \sqrt{13,8197}= \pm 3,717
$$

Reliability interval for SNR value:

$S N R_{\text {confirmation }}-C I_{S N R} \leq S N R_{\text {confirmation }} \leq$

$S N R_{\text {confirmation }}+C I_{S N R}$

$$
49,340 \leq S N R_{\text {confirmation }} \leq 56,774
$$

After getting the reliability interval in optimal condition and confirmation, then a comparison will be applied to find out if confirmation experiment could be accepted. The following is the picture of reliability interval comparison between optimal condition and confirmation either for average value or SNR:

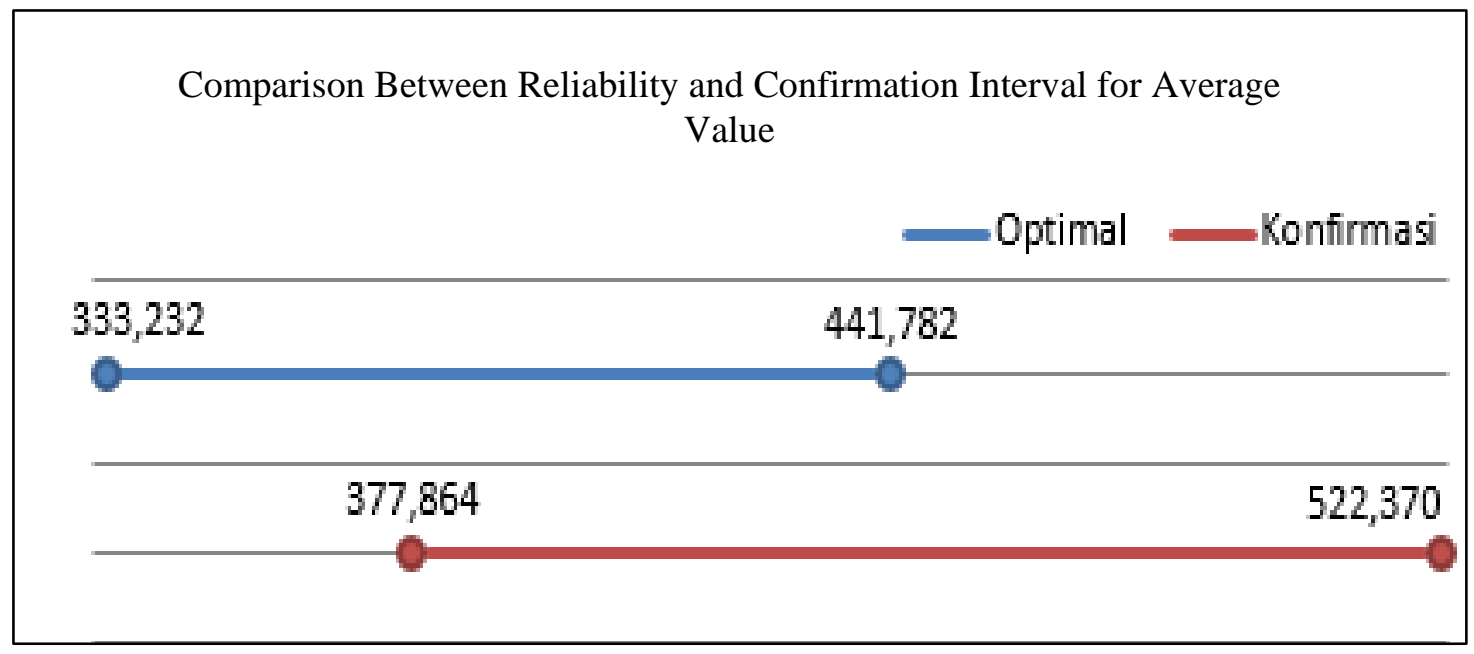

Figure 5. Comparison between Reliability and Confirmation Interval for Average Value 


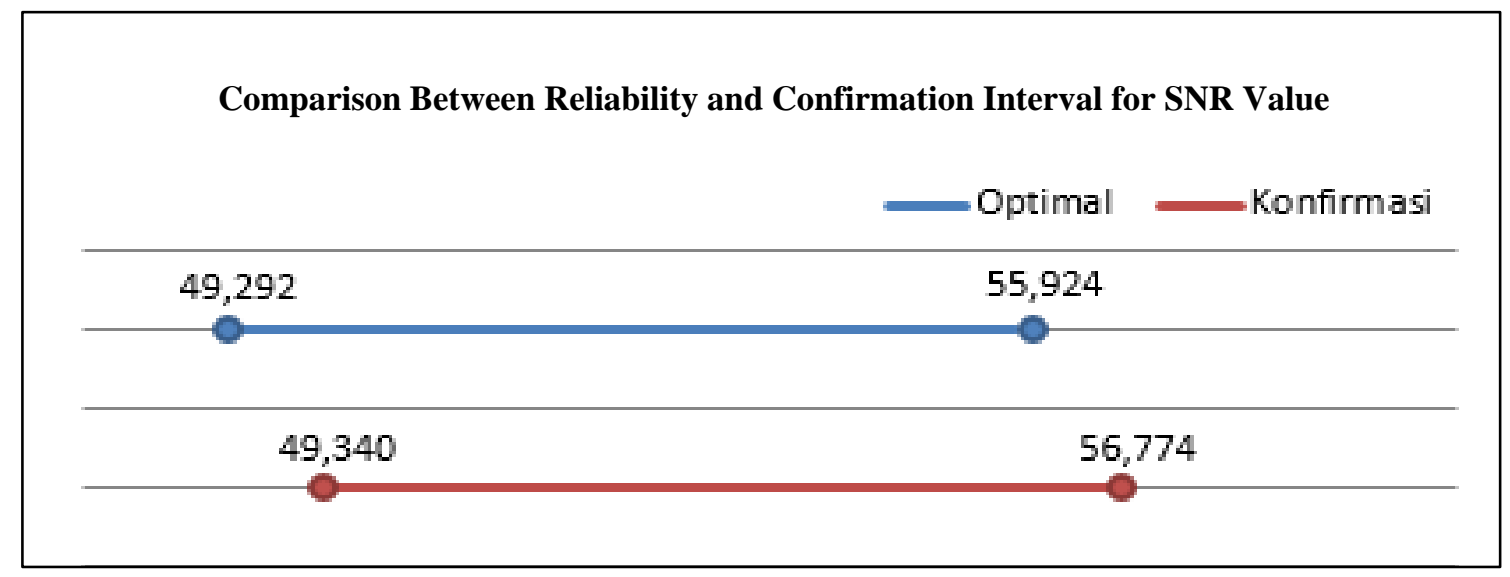

Figure 6. Comparison between Reliability and Confirmation Interval for SNR Value

According to the graphic above, can be seen that the reliability interval lines between optimal condition and confirmation either for average value or SNR is in touch with reliability interval in confirmation experiment lines. Therefore, it can be concluded that the confirmation experiment could be accepted. Besides comparing the reliability interval, in this controlling stage will also be applied a comparison between the pressure power value of the initial paving and the suggested paving. Below is the table of comparison between the pressure durability value of the initial paving and the suggested paving:

Table 11. Pressure Durability between Initial Paving and Suggested Paving

\begin{tabular}{crr}
\hline \multirow{2}{*}{ No. } & \multicolumn{2}{c}{ Pressure Power $\left(\mathrm{kg} / \mathrm{cm}^{2}\right)$} \\
\cline { 2 - 3 } & Initial Paving & Suggested Paving \\
\hline 1 & 48.314 & 464.882 \\
2 & 77.624 & 464.014 \\
3 & 84.722 & 436.080 \\
4 & 96.362 & 444.909 \\
5 & 109.505 & 440.699 \\
\hline Average & 83.305 & 450.117 \\
\hline
\end{tabular}

\section{CONCLUSION}

Based on the research conducted, it can be concluded that the solution for refining the paving quality is by conducting design experiment with Taguchi method. The experiment is conducted for controlling factors such as cement, fly ash, and sand with three levels each. The experiment combination used is by using OA $\mathrm{L}_{9}\left(3^{4}\right)$ matrix. After ANOVA calculation towards average value and SNR is done, it is known that all three factors have significance influence towards paving blocks' pressure durability. The optimum mixture or setting level is $A_{1}, B_{3}$, and $C_{2}$ which the comparison between factors used in the level is 1:3:6 with the mixture of $2 \mathrm{~kg}$ cement, $6 \mathrm{~kg}$ fly ash, and $12 \mathrm{~kg}$ sand. According to the result of reliability interval between the optimal condition and confirmation experiment stated that the confirmation experiment could be accepted. This is proven with confirmation experiment reliability interval lines in touch with the lines in optimal condition. The comparison of pressure durability between initial paving and suggested paving is also indicates that there is a quality improvement where the pressure durability of initial paving is $83,305 \mathrm{~kg} / \mathrm{cm}^{2}$ and the pressure durability of suggested paving have an increase to $450,117 \mathrm{~kg} / \mathrm{cm}^{2}$. According to SNI 03-06911996, the pressure durability of suggested paving could be categorized as category A.

\section{REFERENCES}

[1] Patricia Wahyu Haumahu, 2011, Optimalisasi Produk dengan Menggunakan Metode Perancangan Toleransi Taguchi, Tugas Sarjana, Statistika Matematika FMDPA Universitas Diponegoro, Semarang,.

[2] A. Samadhi, P. F. Opit, dan Y. Singal, 2008, Penerapan Six Sigma untuk Peningkatan Kualitas Produk Bimoli Classic (Studi Kasus: PT. Salim Ivomas Pratama-Bitung), Jurnal Teknik Industri, 3(1):17-24,. 